Jurnal The Messenger, Vol. 12, No. 2, July 2020, pp. 122-133

P-ISSN: 2086-1559, E-ISSN: 2527-2810

DOI: $10.26623 /$ themessenger.v12i2.1939

\title{
The Use of Social Media in Searching for Information about Papua
}

\author{
Panji Dwi Ashrianto ${ }^{1}$, Senja Yustitia ${ }^{1}$ \\ ${ }^{1}$ Department of Communication Science, UPN "Veteran" Yogyakarta, J1. Babarsari No. \\ 2 Tambakbayan, Yogyakarta 55281, Indonesia \\ *Corresponding author, email: senja.yustitia@upnyk.ac.id
}

\begin{abstract}
The use of social media in searching for information relating to political issues has become immensely crucial since in those domains the information appearing is often biased and dominated by certain parties or groups. One of the political information that has frequently emerged in Indonesia is about Papua. The significance of this research because Papua is a crucial problem in Indonesian history, and its conversation has continued, especially in social media. This study intends to examine the use of social media in searching for information about Papua. That is a novelty of research because no one has examined Papua in terms of the use of social media. The Uses and Gratification Theory is used in the study with a mixed method approach as both quantitative and qualitative data were concurrently utilized. Quantitative data obtained from a questionnaire distributed to 100 UPN "Veteran" Yogyakarta students. UPN was selected because they are a state defense campus and provide state defense material to students. While qualitative data from in-depth interviews with some sources. In conclusion, social media cannot be used as the only media for seeking information about Papua. Audiences actively choose the media based on their motivation, experience, and satisfaction.
\end{abstract}

Keywords: Uses and Gratification Theory, Social Media, Papua.

\section{Introduction}

The presence of the internet is changing the way consumption, distribution, and production of messages throughout the world. In the US and UK, BuzzFeed and Vice appear as new pioneers in media production and distribution (Stringer, 2020). Citizen journalism and blogs are also able to change journalism on a participatory side (Kurambayev, 2018; Sukmono \& Junaedi, 2019).

Social media has become a platform employed by the public to share information about anything, from light information to information associated with politics. Some experts even mentioned the presence of social media concerning the public sphere (Fuchs, 2014). In a number of political events, social media has even become a tool for propaganda and raising public opinions (Benoit, Glantz, \& Rill, 2016; Eginli \& Tas, 2018; Wilson \& Lawan, 2015). Some examples are the Save Prita incidence, Gejayan Calls, and the Umbrella Revolution in Hong Kong. Even further, social media is considered capable of mobilizing revolution. Such notion has gained greater prominence since the advent of the Arab Spring phenomenon (Davis \& Santillana, 2019; Niekerk \& Maharaj, 2013).

In Zimbabwe, social media becomes a tool to oppose the ruling regime (Chitanana \& Mutsvairo, 2019), while in Russia it is used for election campaigns (Tomin et al., 2020). Chinese people use WeChat to spread health messages ( $\mathrm{Su}, 2020)$. In social media, we also find various memes and hashtags that use to campaign (Board, 2020; Hoerl, 2019). In Indonesia, various information in politics often circulate on social media. Even back in 2018, a researcher from LIPI (Indonesian Institute of Sciences), Wasisto R. Jati, had already stated that social media will be used as a platform for political proxy (Jati, 2018).

One of the themes that often emerges on social media in Indonesia is that relating

Article History: Received February 17, 2020; Revised July 20, 2020; Accepted July 26, 2020; Published July 31, 2020 
to issues of Papua. Drone Emprit data indicates that in the last 3 years, netizen conversations relating to 'West Papua' had been carried out daily. The narrative had consistently existed on social media, particularly on Twitter since September 2016 until September 2019 (Fahmi, 2019b). Even the internet blockade in Papua had not deterred conversations about 'West Papua' (Fahmi, 2019a).

Aside from the reality presented on social media, the fact of the matter is that the Papua conflict has perhaps been the longest running issue in the history of Indonesia. According to Cahyo Pamungkas, political violence in Papua is the longest separatist conflict compared to the conflict in Aceh and East Timor (Pamungkas, 2017). In 2019, the conflict in Papua regained notoriety following the attack on Papua dormitory incident in Surabaya perpetrated by a number of individuals. The incident had subsequently led to a series of demonstrations conducted by students, Papua residents, and activists in several locations (Baskoro, 2019; Doherty, 2019). The government had also taken several measures, by pursuing legal means and a policy of limiting internet access to minimize developing fake news (Boediwardhana, 2019; DS, 2019; Firdaus, 2019).

Nevertheless, the presence of social media is not without risks. Some of the emerging issues are the abundance of fake news and polarization. Fake news may even lead to altering the political orientation of a country as witnessed in the Brexit Referendum and the 2016 United States Presidential election (Gelfert, 2018). Moreover, another negative aspect of social media is mentioned in detail by Kumar and Shah as false information (Kumar \& Shah, 2018; Syam \& Nurrahmi, 2020). The dissemination of false narratives and information, social media algorithms also correlate with political polarization (Levy \& Sarmento, 2020; Ribeiro, Calais, Almeida, \& Jr, 2017). Accordingly, skills relating to media and information literacy is highly required (Maryani, 2014; Opiyo \& Kuruc, 2016).

The use of social media as a tool to search for information becomes even more crucial in political issues involving conflicts. During an event of conflict, among the most frequently occurring issues are information uncertainties, domination of one group's information over another, and information contents that tend to be biased. This is exacerbated by the public's extremely easy access to social media. There is almost no special requirement for an individual to set-up and have a social media account. Even anonymous accounts thrive and are trusted by the audience.

How audiences consume information about politics on social media and instant messaging applications is examined by Fernandez et al (Fernández \& Rodríguez-Virgili, 2019). This research compares patterns in consuming information between general voters, and other audiences such as journalists, academics, consultants, and political leaders. This research shows that everyone chooses social media based on their specific needs and motivations. Another research linking the use of social media with attitude was conducted by Gita and Errika (Aprinta \& Dwi, 2017).

Based on the elaborations provided in the above, the researchers intend to examine the use of social media in searching for information about Papua. The extensive Papua conflict in Indonesia demands complete and immediate resolution. Meanwhile, social media is a communication platform significantly used by the public. The government's measure of blocking the internet access in Papua also indicates that there were efforts to limit information in order to avoid confusion.

Scholars have conducted numerous studies about Papua, yet, they are more focused on the political reality than social media activities. For instance, a study by Cahyo Pamungkas highlights the series of peaceful campaign carried out by the Papua Peace 
Network (PPN) throughout the period of 2013-2017 (Pamungkas, 2017). The historical and political reality of Papua was also analyzed by Ali Muhammad (Muhammad, 2013) and Leslie (Rollings, 2010). The Papua conflict, seen from the eyes of mainstream media in Papua New Guinea, shows that there is a decreasing press coverage found in 3 media outlets, namely Post-Courier, The National, and Times of Papua New Guinea (Matbob \& Papoutsaki, 2006). In general, research on Papua previously focused more on aspects of government policy and the Papuan community movement. Some others talk about how the phenomenon of news on the mainstream media. While this research is more focused on the audience (audience research) which is part of the audience exposed to the pro/ antiPapuan independent community movement as well as mainstream media coverage. Accordingly, this research is expected to provide novel information that has not been discussed in previous studies.

The significance of this research is related to 3 things. First, Papua is an unfinished problem and needs a comprehensive solution. Second, the attack on the Papua dormitory in Surabaya is a reflection that matters relating to the production, consumption, and distribution of messages, including on social media, are crucial because they can result in people's views and actions on the problem. Third, because this research conducted on students who are representatives of the younger generation in Indonesia, this study is expected to be able to give an idea of how this generation uses social media, especially related to information about Papua. The results of this research can be part of a future study of social media literacy.

This research employed the Uses and Gratification Theory (UGT), which maintains a number of key assumptions. First, the audience is active and they have specific goals in media consumption. Second, the media ultimately competes with other resources in relation to need satisfaction. Finally, value judgments of media content can only be assessed by the audience. This means that each individual may present a different assessment (Child \& Haridakis, 2018; Muyingo, 2017; Samani \& Guri, 2019). This theory also focuses on the question 'how' and 'why' and highlights social psychological factors that can create the needs and expectations of the audience of the mass media or other sources of information (M. Adnan \& Mavi, 2015; Prisgunanto, 2020).

\section{Methods}

The mixed method is empoloyed in the study. According to Schoonenboom and Johnson, the mixed method implies research that combines the use of qualitative and quantitative elements to achieve breadth and depth of study (Schoonenboom \& Johnson, 2017). This approach used so that researchers can explore aspects of 'how' and 'why' related to information seeking about Papua. The use of these two approaches at the audience level has not been using by studies that discussed Papua before.

The quantitative data were obtained through a survey conducted on a sample of 100 university students of UPN "Veteran" Yogyakarta, which was then used to test the correlation between the behavior of social media use ( $\mathrm{x}$ variable) and the students' concern about issues of Papua (y variable). The sample amount was acquired from a population of 9,610 by using the formula $n=N /\left(1+\mathrm{Ne}^{2}\right)$ with a 0.1 margin of error. The Likert scale was used as a measuring tool with validity test conducted by employing Pearson correlations, while reliability test achieved by computing Cronbach's alpha coefficient. The interesting data obtained from the survey results were subsequently explored further by carrying out open inquiries through interviews to seek even deeper insight into the use of social media to search for information about Papua issues. 


\section{Results}

In this section, results of the quantitative research are initially discussed including emphasis on intriguing data that would later function as the basis for interviews conducted with the source persons. Based on the SPSS calculation conducted, in the t-test the tcount value is at 9.902 while the ttable value at 1.660 where tcount $>$ ttable $(9.902>1.660)$. This indicates that there is significant positive effect of the social media use variable to students' concern. The higher the social media use behavior is, the better the students' concern about Papua issues becomes.

Table 1. Hypothesis Testing

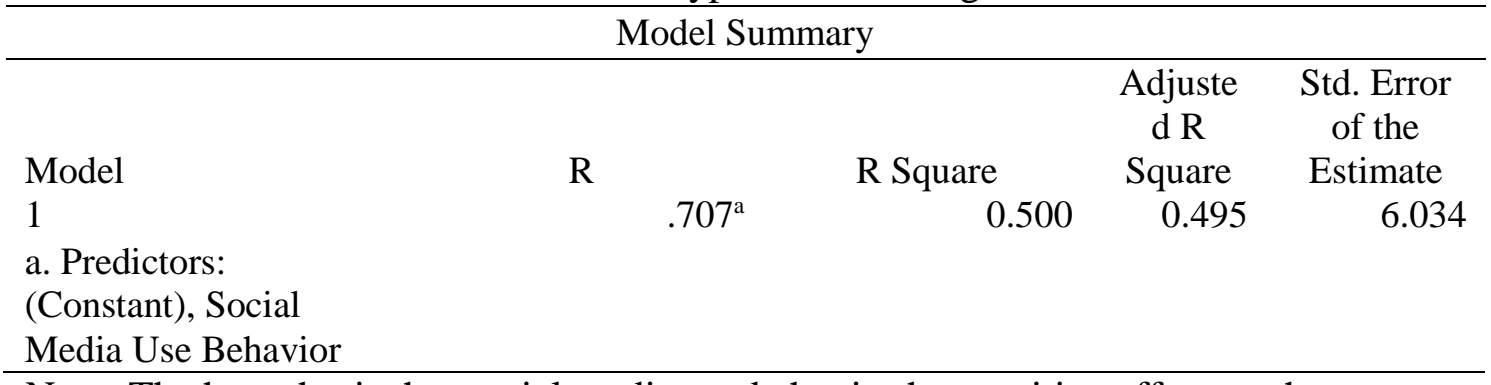

Note: The hypothesis that social media use behavior has positive effect on the concern of UPN "Veteran" Yogyakarta students about Papua issues is acceptable (source: Primary Data, 2019)

The coefficient of determination or R-squared is at 0.500 indicating that $50 \%$ of variations on the dependent variable (students' concern about Papua issues) can be explained by the independent variable (social media use behavior). The remaining 50\% is affected by variables that are not explained in the study. The hypothesis that social media use behavior has positive effect on the concern of UPN "Veteran" Yogyakarta students about Papua issues is acceptable. The use of social media here does not only focus on or refer to the duration of use but also social media behavior that has a more qualitative understanding.

In general, there were several interesting data produced by the quantitative research, which would then be explored deeper through interviews. The following table is presented to simplify the data:

Table 2. Social Media Use about Behavior of Respondents

\begin{tabular}{|c|c|c|c|c|c|c|}
\hline No & $\begin{array}{c}\text { Social Media Use Behavior } \\
\text { Variable (x) }\end{array}$ & $\begin{array}{l}\text { Strongly } \\
\text { agree }\end{array}$ & Agree & $\begin{array}{l}\text { Scale }(\%) \\
\text { Undecided }\end{array}$ & Disagree & $\begin{array}{l}\text { Strongly } \\
\text { disagree }\end{array}$ \\
\hline 1 & $\begin{array}{c}\text { I access social media with } \\
\text { contents relating to issues of } \\
\text { Papua daily. }\end{array}$ & 0 & 7 & 30 & 55 & 8 \\
\hline 2 & $\begin{array}{l}\text { I access social media with } \\
\text { contents relating to issues of } \\
\text { Papua more than } 3 \text { hours/day. }\end{array}$ & 1 & 2 & 14 & 65 & 18 \\
\hline 3 & $\begin{array}{c}\text { I access more than one type } \\
\text { of social media/day to be } \\
\text { informed about issues } \\
\text { of Papua. }\end{array}$ & 5 & 33 & 19 & 33 & 10 \\
\hline 4 & $\begin{array}{c}\text { I read/watch contents relating } \\
\text { to issues of Papua on social } \\
\text { media thoroughly. }\end{array}$ & 9 & 38 & 28 & 20 & 5 \\
\hline
\end{tabular}




\begin{tabular}{|c|c|c|c|c|c|c|}
\hline 5 & $\begin{array}{l}\text { I compare contents relating to } \\
\text { issues of Papua among } \\
\text { various social media outlets. }\end{array}$ & 20 & 17 & 26 & 29 & 8 \\
\hline 6 & $\begin{array}{l}\text { I read/watch issues of Papua } \\
\text { on social media based on } \\
\text { recommendations of others. }\end{array}$ & 5 & 28 & 24 & 34 & 9 \\
\hline 7 & $\begin{array}{l}\text { I read/watch social media } \\
\text { contents relating to viral } \\
\text { Papua issues. }\end{array}$ & 16 & 54 & 14 & 11 & 5 \\
\hline 8 & $\begin{array}{l}\text { I constantly follow issues of } \\
\text { Papua that become trending } \\
\text { topics on social media. }\end{array}$ & 6 & 20 & 36 & 30 & 8 \\
\hline 9 & $\begin{array}{l}\text { I read/watch social media } \\
\text { contents relating to issues of } \\
\text { Papua that I like. }\end{array}$ & 4 & 43 & 27 & 18 & 8 \\
\hline 10 & $\begin{array}{l}\text { I believe in all social media } \\
\text { contents relating to issues } \\
\text { of Papua. }\end{array}$ & 0 & 4 & 40 & 43 & 13 \\
\hline 11 & $\begin{array}{l}\text { I am certain that accessing } \\
\text { social media is the most } \\
\text { adequate means to } \\
\text { understand about the issues } \\
\text { of Papua. }\end{array}$ & 4 & 28 & 35 & 27 & 6 \\
\hline 12 & $\begin{array}{l}\text { I think a deep understanding } \\
\text { on Papua issues is obtained } \\
\text { on social media. }\end{array}$ & 5 & 31 & 43 & 18 & 3 \\
\hline 13 & $\begin{array}{l}\text { I actively access social media } \\
\text { by giving likes/comments/ } \\
\text { reports/retweets/subscribes to } \\
\text { contents relating to issues } \\
\text { of Papua. }\end{array}$ & 2 & 12 & 32 & 41 & 13 \\
\hline
\end{tabular}

Note: The use of Social Media is related to the Papua issues (source: Primary Data, 2019)

According to Table 2 data, there are at least 4 matters relating to the use of social media, which involve activities of comparing, believing in, being certain of, and deep understanding of contents on social media. The data shows that activities to compare and not compare has the same amount of percentage. Additionally, the respondents do not believe in all the social media contents relating to issues of Papua. As for conviction or certainty and depth, they are also not entirely sure that social media provides deep understanding. Social media is also not considered as the most appropriate means to understand about issues of Papua.

Table 3. Respondents' Concern about Issues of Papua

\begin{tabular}{ccccccc}
\hline No & Concern about Issues of Papua \\
Variable (y) & $\begin{array}{c}\text { Strongly } \\
\text { agree }\end{array}$ & Agree & $\begin{array}{c}\text { Scale (\%) } \\
\text { Undecided }\end{array}$ & Disagree & $\begin{array}{c}\text { Strongly } \\
\text { disagree }\end{array}$ \\
\hline 1 & $\begin{array}{c}\text { I know about information } \\
\text { relating to issues of Papua. }\end{array}$ & 6 & 50 & 28 & 12 & 4 \\
2 & 2 & 24 & 50 & 20 & 4 \\
$\begin{array}{c}\text { I know about the development } \\
\text { of information relating to } \\
\text { issues of Papua. }\end{array}$ & & & & & \\
\hline
\end{tabular}




\begin{tabular}{|c|c|c|c|c|c|c|}
\hline 3 & $\begin{array}{l}\text { I attempt to seek information } \\
\text { about issues of Papua that } \\
\text { I don't know. }\end{array}$ & 4 & 42 & 37 & 10 & 7 \\
\hline 4 & $\begin{array}{c}\text { I consider issues of Papua } \\
\text { as important. }\end{array}$ & 21 & 55 & 21 & 0 & 3 \\
\hline 5 & $\begin{array}{l}\text { I consider issues of Papua } \\
\text { as interesting. }\end{array}$ & 20 & 48 & 29 & 1 & 2 \\
\hline 6 & $\begin{array}{l}\text { I empathize with the people } \\
\text { of Papua. }\end{array}$ & 32 & 60 & 7 & 0 & 1 \\
\hline 7 & $\begin{array}{l}\text { I think that issues of Papua } \\
\text { have resulted in Indonesia } \\
\text { gaining international attention. }\end{array}$ & 19 & 52 & 26 & 2 & 1 \\
\hline 8 & $\begin{array}{l}\text { I think that issues of Papua } \\
\text { affect the credibility of the } \\
\text { Indonesian government. }\end{array}$ & 26 & 52 & 20 & 1 & 1 \\
\hline 9 & $\begin{array}{l}\text { I try to confirm information } \\
\text { relating to issues of Papua } \\
\text { with others. }\end{array}$ & 10 & 36 & 43 & 9 & 2 \\
\hline 10 & $\begin{array}{l}\text { I try to confirm information } \\
\text { relating to issues of Papua } \\
\text { with others I consider more } \\
\text { knowledgeable. }\end{array}$ & 17 & 45 & 27 & 9 & 2 \\
\hline 11 & $\begin{array}{c}\text { I think I need to be actively } \\
\text { involved in voicing aspirations } \\
\text { about Papua issues. }\end{array}$ & 7 & 35 & 50 & 6 & 2 \\
\hline 12 & $\begin{array}{l}\text { I think I need to call on others } \\
\text { to be actively involved in } \\
\text { voicing aspirations about } \\
\text { Papua issues. }\end{array}$ & 7 & 42 & 42 & 6 & 3 \\
\hline 13 & $\begin{array}{c}\text { I talk about issues of Papua } \\
\text { with people in } \\
\text { my closest circle. }\end{array}$ & 8 & 42 & 33 & 14 & 3 \\
\hline 14 & $\begin{array}{c}\text { I think I need to participate in } \\
\text { real actions to express } \\
\text { Papua issues. }\end{array}$ & 3 & 16 & 55 & 22 & 4 \\
\hline 15 & $\begin{array}{l}\text { I think the government needs } \\
\text { to take actions responding to } \\
\text { issues of Papua. }\end{array}$ & 45,5 & 45,5 & 8 & 0 & 1 \\
\hline 16 & $\begin{array}{l}\text { I think Indonesians need to } \\
\text { respond to issues of Papua } \\
\text { more actively. }\end{array}$ & 42 & 45 & 11 & 0 & 2 \\
\hline
\end{tabular}

Note: Respondents' Concern (source: Primary Data, 2019)

Table 3 provides interesting data pertaining to confirmation activities and to whom do the respondents confirm them. This correlates with Table 2 data which indicates that respondents think social media does not provide depth of understanding and that it is not the most appropriate platform for knowing about issues of Papua. Table 3 shows that there are activities in which respondents confirm Papua issues to those more knowledgeable about them, including their closest circle. Such social media activities are quite positive since respondents maintain a critical attitude and they attempt to process the information.

The next interesting thing is that 5 of the interviewed sources stated that non-social media channels are in fact more reliable for achieving information credibility. Social 
media only excels in providing them service with speed and diversity. What is meant by diversity here is social media's capacity to present viewpoints of individuals, groups, or parties that have never before been shown by web news, newspapers, radio, and television. Nevertheless, the diversity of information is not without its risks. The biggest risk is that any individual has the potential of fabricating information. This implies that there is highly significant possibility of misinformation, such as fake news and hoaxes, occurring.

\section{Discussion}

Figure 1 shows that concerning issues of Papua, social media cannot be used as the only information channel. The main reason being that social media resources are unable to fulfill the audience's need for depth and credibility. Information on Papua, for instance relating to the attack on the dormitory, anti-racist rallies in some cities throughout Indonesia, the Free West Papua movement, and even the emergence of figures like Benny Wenda and Veronika Koman, according to the respondents, are difficult to understand by using social media alone. The long history of conflict in Papua has led respondents of the study to agree that understanding Papua requires the use of various media including intensive face-to-face activities.

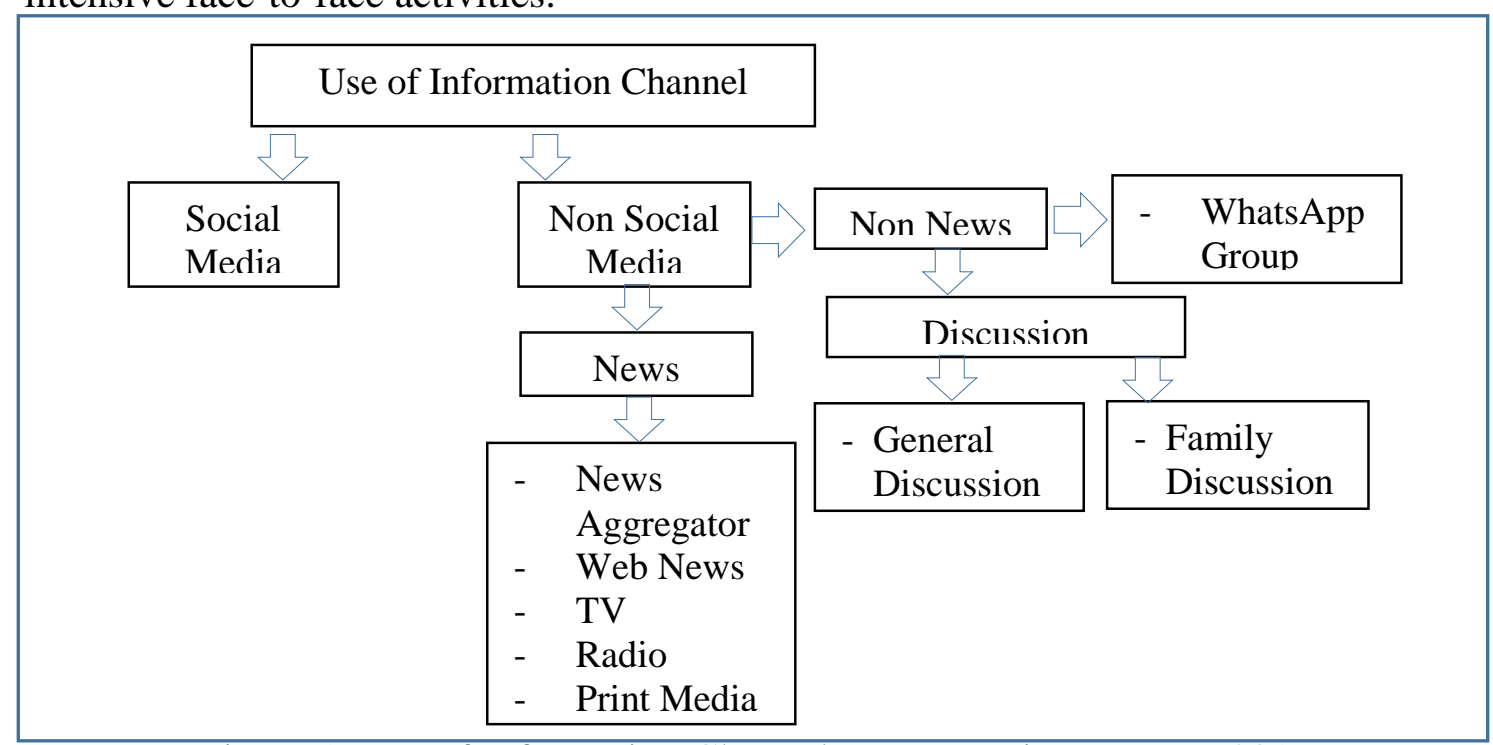

Figure 1. Use of Information Channel (source: Primary Data, 2019)

The following figure is presented to provide an understanding of the needs that can be fulfilled by each of the information channel:

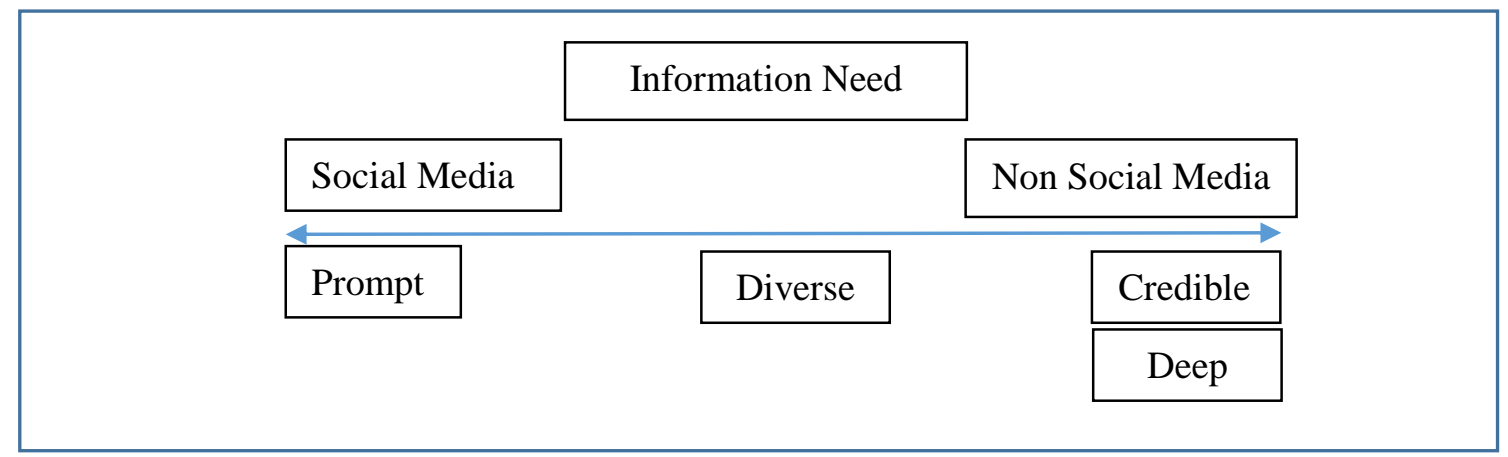

Figure 2. Information Need (source: Primary Data, 2019)

Figure 2 shows that social media offers promptness, while non-social media channel maintains depth and high credibility. As for diversity, it is positioned in the 
middle as social media does indeed maintain diversity although it also depends on the user. As long as the user makes no attempt to seek diversity by merely selecting news sources from those they favor, and given the support of social media algorithms, diversity of information sources would not be achieved. Conversely, in non-social media channels, there are limitations that are often inferred by the audience, for instance mainstream media only rely on elite source persons. This means that the aspect of diversity is highly dependent on the user's media use behavior.

Based on the findings, it is apparent that a user's motivation and experience is essential in social media use to search for information about Papua. This is in line with the basic assumptions of UGT (Child \& Haridakis, 2018; Muyingo, 2017; Samani \& Guri, 2019). The audience are now believed to be extremely active in selecting the media they use, and it is goal directed. Preference or motivation highly correlates with experience. The reality wherein the media in Indonesia is often caught up with elitist and the same old sources eventually results in social media being used to provide more diversity. However, they are also aware that diversity on social media also opens up opportunities for certain individuals or groups to produce messages for the interest of propaganda and without having adequate data. In addition, misinformation has also become exceedingly more open. Public and family discussions are used as a media to obtain and confirm information. A respondent of this study stated that he/she is in fact more interested in the interactivity performed by the individuals involved in the discussions, in terms of both the audience and the figure presented. Similar interactivity is actually an advantage that social media has. However, the high level of distortion potential observed on social media may lead to reducing the essence of interactivity.

Concerning media use and preference in relation to satisfaction, media use that combines social media and non-social media to search for information about Papua is also based on satisfaction. Experience and satisfaction are the reason that every individual has different value judgments of every media. It is interesting to note that all this time the millennial and $\mathrm{z}$ generations are often considered as the group that is extremely intimate with social media use, yet this study indicates that it is not entirely true. Social media is used along with other media in order to satisfy their information need in terms of promptness, diversity, and depth.

The results of this research also fill the void of research that examines the Papua problem. Rollings, Pamungkas, and Muhammad focus on those directly related to the West Papua problem. Rollings, for example, concludes that the Indonesian government's policy has aroused Papuan nationalism for independence (Rollings, 2010). While Muhammad said, the Dutch colonial government's policies contributed to the strengthening of the aspirations of West Papua separating from Indonesia (Muhammad, 2013). Pamungkas research focuses on the Papua Peace Network (PPN) campaign and policy by the Indonesian government (Pamungkas, 2017). Matbob's approach is somewhat different by discussing the realm of media. He focused on reporting three newspapers in Papua New Guinea (PNG) and interviewing West Papuan refugees in PNG (Matbob \& Papoutsaki, 2006). However, Matbob does not research at a broad reader level. It shows not yet a study that examines the audience, which is not directly related to the Papua issue but exposed to information about Papua.

It shows that this research fills a void that has not yet been fulfilled by other research while at the same time shifting the Papua problem not only about the Indonesian policy towards the people of Papua. If Papua is a crucial problem in Indonesian history, then this problem concerns all the people of Indonesia. 
With the massive social media and freedom of information, the results of this study are valuable input for audience and media stakeholders (non-social media). Referring to the conclusion of Matbob's research that there has been a dramatic decline in Papua New Guinea (Post Courier, The National and Time of Papua New Guinea) press coverage of West Papua over the past 20 years (Matbob \& Papoutsaki, 2006). One reason is the dependence of newspapers with international news sources when covering West Papua. It shows that aspects of diversity are urgent. A variety of information becomes the needs of the audience, especially on conflict news, that is why consuming social media and nonsocial media as well as being a vital need.

\section{Conclusion}

The hypothesis that social media use behavior has positive effect on the concern of UPN "Veteran" Yogyakarta students about Papua issues is acceptable. The use of social media here does not only focus on or refer to the duration of use but also social media behavior that has a more qualitative understanding. This research concluded that social media cannot be used as the only media to search for information about Papua. Social media has a set of limitations requiring its audience to utilize other channels including through face-to-face engagements such as discussions. Varied media use is a rather positive phenomenon amidst the abundance of fake news or misinformation, which means that there is a form of media literacy in place by being aware that there is no one channel capable of satisfying all of the audience's needs and that there is willingness to seek other sources. This study may eventually be developed into further studies, for instance, by observing what media are used by Papuans in exchanging information. This has yet to be answered in this research and it is also a limitation that can expectedly be developed in future studies.

\section{Conflict of Interest}

We certify that there is no conflict of interest with any financial, personal, or other relationships with other people or organization related to the material discussed in the manuscript.

\section{Acknowledgements}

The researchers would like to express their utmost gratitude to the Research and Community Service Institute ('Lembaga Penelitian dan Pengabdian Masyarakat' (LPPM)) of UPN "Veteran" Yogyakarta for having funded and facilitated the research to its completion.

\section{References}

Aprinta, G., \& Dwi, E. (2017). Hubungan Penggunaan Media Sosial Dengan Tingkat Kepekaan Sosial Di Usia Remaja Correlation of Social Media Uses and Social Consciousness Level in Teenagers. Jurnal The Messenger, 9(1), 65-69.

Baskoro, Y. (2019). "I Am Not a Monkey": Papuans Protest Against Racial Discrimination. Retrieved February 15, 2020, from Jakarta Globe website: https://jakartaglobe.id/vision/i-am-not-a-monkey-papuans-protest-against-racialdiscrimination

Benoit, W. L., Glantz, M., \& Rill, L. (2016). Campaigning on the internet: 2008 presidential general election candidate webpages. Kome, 4(2), 46-58. https://doi.org/10.17646/KOME.2016.24 
Board, W. E. (2020). Viral culture, memes in society and politics: An interview with Anastasia denisova. Westminster Papers in Communication and Culture, 15(1), 74 79. https://doi.org/10.16997/WPCC.366

Boediwardhana, W. (2019). East Java Police name another suspect related to racist abuse against Papuan students. Retrieved February 15, 2020, from The Jakarta Post website: https://www.thejakartapost.com/news/2019/08/31/east-java-police-nameanother-suspect-related-to-racist-abuse-against-papuan-students.html

Child, J. T., \& Haridakis, P. (2018). Uses and Gratifications Theory. Engaging Theories in Family Communication, 337-348. https://doi.org/10.4324/9781315204321-30

Chitanana, T., \& Mutsvairo, B. (2019). The Deferred 'Democracy Dividend' of Citizen Journalism and Social Media: Perils, Promises and Prospects from the Zimbabwean Experience. Westminster Papers in Communication and Culture, 14(1), 66-80. https://doi.org/10.16997/wpcc.316

Davis, S., \& Santillana, M. (2019). From the Streets to the Screen to Nowhere: Las Morras and the Fragility of Networked Digital Activism. Westminster Papers in Communication and Culture, 14(1), 18-32. https://doi.org/10.16997/wpcc.308

Doherty, B. (2019). Up to seven dead in West Papua as protest turns violent. Retrieved February 15, 2020, from The Guardian website: https://www.theguardian.com/world/2019/aug/29/west-papua-deaths-as-protestturns-violent

DS, I. (2019). Internet blackout in Papua, cure or curse? Retrieved February 15, 2020, from The Jakarta Post website: https://www.thejakartapost.com/academia/2019/08/29/internet-blackout-in-papuacure-or-curse.html

Eginli, A. T., \& Tas, N. O. (2018). Interpersonal Communication in Social Networking Sites: An Investigation in the Framework of Uses and Gratification Theory. Online Journal of Communication and Media Technologies, 8(2), 81-104.

Fahmi, I. (2019a). MESKI INTERNET DIBLOKIR, PERCAKAPAN "WEST PAPUA" TETAP MENINGKAT. Retrieved October 8, 2019, from Drone Emprit website: https://pers.droneemprit.id/meski-internet-diblokir-percakapan-west-papua-tetapmeningkat/

Fahmi, I. (2019b). SETENGAH BULAN LEBIH, PRO "FREE WEST PAPUA" TETAP PENGUASA NARASI INTERNASIONAL. Retrieved February 15, 2020, from Drone Emprit website: https://pers.droneemprit.id/setengah-bulan-lebih-pro-freewest-papua-tetap-penguasa-narasi-internasional/

Fernández, C. B., \& Rodríguez-Virgili, J. (2019). Electors are from facebook, political geeks are from twitter: Political information consumption in Argentina, Spain and 1 Venezuela. Kome, 7(1), 42-62. https://doi.org/10.17646/KOME.75698.62

Firdaus, F. (2019). Indonesia blocks internet in West Papua as protest rages. Retrieved February 15, 2020, from Al Jazeera website: https://www.aljazeera.com/news/2019/08/indonesia-blocks-internet-west-papuaprotest-rages-190822022809234.html

Fuchs, C. (2014). Social media and the public sphere. TripleC, 12(1), 57-101. https://doi.org/10.31269/vol12iss1pp57-101

Gelfert, A. (2018). Fake News: A Definition. Informal Logic, 38(1), 84-117.

Hoerl, K. (2019). Special Issue: The \#MeToo Moment: A Rhetorical Zeitgeist. Women's $\begin{array}{llll}\text { Studies in } & \text { Communication, }\end{array}$ https://doi.org/10.1080/07491409.2019.1652530 
Jati, W. R. (2018). Media Sosial sebagai Perang Proksi Politik 2019. Retrieved February 15, 2020, from Media Indonesia website: https://mediaindonesia.com/read/detail/197392-media-sosial-sebagai-perangproksi-politik-2019

Kumar, S., \& Shah, N. (2018). False Information on Web and Social Media: A Survey. Retrieved from http://arxiv.org/abs/1804.08559

Kurambayev, B. (2018). Blogging Gratifies Engagement Need for Internet Users in Media-Constrained Environment. Online Journal of Communication and Media Technologies, 8(2), 1-25.

Levy, H., \& Sarmento, C. (2020). Understanding viral communism: A thematic analysis of twitter during Brazil's 2018 elections. Westminster Papers in Communication and Culture, 15(1), 19-36. https://doi.org/10.16997/WPCC.322

M. Adnan, H., \& Mavi, S. R. (2015). Facebook Satisfaction, Life Satisfaction: Malaysian Undergraduate Experience. Jurnal Komunikasi, Malaysian Journal of Communication, 31(2), 649-671. https://doi.org/10.17576/jkmjc-2015-3102-37

Maryani, E. (2014). Developing Media Literacy Model for Children With Social and Cultural Approach. Online Journal of Communication and Media Technologies, (October), 12-25.

Matbob, P., \& Papoutsaki, E. (2006). West Papuan 'independence' and the Papua New Guinea press. Pacific Journalism Review, 12(2), 87-105.

Muhammad, A. (2013). The Historical Origins of Secessionist Movement in West Papua. Journal of Asia Pacific Studies, 3(1), 1-13. Retrieved from http://www.japss.org/upload/1. Ali.pdf

Muyingo, R. I. (2017). Usage and Gratification of Social Media in Higher Education: A Survey on the Perceptions of International Students in Turkey. Online Journal of Communication and Media Technologies, 7(3), 159-181.

Niekerk, B. Van, \& Maharaj, M. (2013). Social Media and Information Conflict. International Journal of Communication, 7, 1162-1184. https://doi.org/10.4018/978-1-4666-9518-4.les2

Opiyo, B., \& Kuruc, U. K. (2016). Mediated Digital Activism: A Critical Assessment of Opportunities, Promises and Problems of Social Media Uses in Contemporary Grassroots Movements. Online Journal of Communication and Media Technologies, (December), 121-148.

Pamungkas, C. (2017). The Campaign of Papua Peace Network for Papua Peace Land. Jurnal Ilmu Sosial Dan Ilmu Politik, 21(2), 147. https://doi.org/10.22146/jsp.30440

Prisgunanto, I. (2020). Social media and visit decision to tourist destinations: Measuring the impact of instagram on expatriates in Indonesia. Jurnal Komunikasi: Malaysian Journal of Communication, 36(1), 495-508. https://doi.org/10.17576/JKMJC2020-3601-29

Ribeiro, M., Calais, P. H., Almeida, V., \& Jr, W. M. (2017). "Everything I Disagree With is \# FakeNews ": Correlating Political Polarization and Spread of Misinformation. Data Science + Journalism2. https://doi.org/10.475/123

Rollings, L. B. (2010). The West Papua dilemma. University of Wollongong.

Samani, M. C., \& Guri, C. J. (2019). Revisiting uses and gratification theory: A study on visitors to annah rais homestay. Jurnal Komunikasi: Malaysian Journal of Communication, 35(1), 206-221. https://doi.org/10.17576/JKMJC-2019-3501-14

Schoonenboom, J., \& Johnson, R. B. (2017). Wie man ein Mixed Methods-ForschungsDesign konstruiert. Kolner Zeitschrift Fur Soziologie Und Sozialpsychologie, 69, 
107-131. https://doi.org/10.1007/s11577-017-0454-1

Stringer, P. (2020). Viral media: Audience engagement and editorial autonomy at buzzfeed and vice. Westminster Papers in Communication and Culture, 15(1), 518. https://doi.org/10.16997/WPCC.324

$\mathrm{Su}, \mathrm{X}$. (2020). Content Analysis of HPV Vaccine Messages on Chinese Social Media. $\begin{array}{llll}\text { Jurnal The } & \text { Messenger, }\end{array}$ https://doi.org/10.26623/themessenger.v12i1.1814

Sukmono, F. G., \& Junaedi, F. (2019). Citizen Journalism and Online Community Media: A Case Study of pwmu.co. Jurnal The Messenger, 11(2), 198-208. https://doi.org/http://dx.doi.org/10.26623/themessenger.v11i2.1173

Syam, H. M., \& Nurrahmi, F. (2020). "I Don't Know If It Is Fake or Real News" How Little Indonesian University Students Understand Social Media Literacy. Jurnal Komunikasi: Malaysian Journal of Communication, 36(2), 92-105. https://doi.org/10.17576/JKMJC-2020-3602-06

Tomin, V. V., Erofeeva, N. E., Borzova, T. V., Lisitzina, T. B., Rubanik, V. E., Aliyev, H. K., \& Shuaipova, P. G. (2020). Internet Media as Component of Information and Communication Environment in Electoral Process: Features and Tools. Online Journal of Communication and Media Technologies, 10(3). https://doi.org/10.29333/ojcmt/7932

Wilson, J., \& Lawan, A. K. (2015). The internet and the Nigerian woman: A case of female undergraduates. Kome, 3(1), 47-64. https://doi.org/10.17646/KOME.2015.14 